\title{
Human Rights and Human Dignity: A Case Against Separating the Conjoined Twins
}

\author{
Kebadu Mekonnen Gebremariam*
}

\begin{abstract}
Doris Schroeder asserts that the received view according to which human rights are derived from the inherent dignity of the human person must be rejected. She appeals to separate these conjoined twins (human dignity and human rights) by offering three knockdown arguments respectively captioned as "the justification paradox", "Kantian cul-de-sac" and "hazard by association". This paper submits a case for preserving the conjoined twins, both by refuting Schroeder's arguments and at the same time proposing a positive appraisal of human dignity as foundational to human rights. The distributive account of a foundation, on which Schroeder's arguments are premised, requires that a normative foundation must underpin every single human rights claim. Human rights claims, as diverse as they are, admit plurality of normative foundations (understood in the distributive sense) and human dignity directly underpins only a subset of the most basic human rights. There is another sense in which human dignity can be conceived as foundational to human rights, precisely as the general moral standing of human beings as holders of the bundle of moral human rights. Foundation as moral standing is consistent with the view that not every human rights-claim has its normative foundation in human dignity; thus, Schroeder is mistaken in thinking that failing to be a foundation in the distributive sense defeats the accepted view that human rights derive from human dignity.
\end{abstract}

Keywords: Human rights, inherent dignity, moral standing, normative foundation, Schroeder

DOI: https://dx.doi.org/10.1314/ejossah.v16i1.5

*Assistant professor, Department of Philosophy, Addis Ababa University, Email: kebadum@gmail.com, Tel: +251904592351, P.O. Box: 1176/ Addis Ababa

This work is licensed to the publisher under the Creative CommonsAttribution-NonCommercialNoDerivs License. 


\section{Introduction}

Human dignity's renewed currency in the philosophical discourse is often punctuated by sharp and often irreconcilable disagreements. The discourse is characterised by a clash between two opposing views, between radical scepticism to human dignity's normative significance to human rights and the dogmatic view which asserts that "rights humans have as humans are based on dignity" (Schaber 2013). Proponents of the latter view maintain that a compelling case can be made for the received view that the concept of human dignity is indispensable to the constitution of fundamental human rights (Waldron, 2009, 2012, 2013; Gewirth, $1992 \&$ Tasioulas, 2012, 2013). They submit that human rights are grounded on the moral framework within which the concept of human dignity is to be found. As humans, we have dignity and thus possess certain fundamental rights.

This paper pivots on one situated debate within the general discourse concerning the foundation of human rights between a radical critic and a fervent proponent of a dignitarian foundation of human rights-namely Doris Schroeder and Peter Schaber respectively. Schroeder argues that an attempt to ground human rights in human dignity is bound to fail. Central to Schroeder's argument is the presumption that the contemporary notion of human dignity is borrowed from the religious idea of Imago Dei; whereas, the most promising secular variant-the Kantian conception, with its attendant focus on rational agency as the principal locus of our dignity, deviates from the egalitarian idea that human rights are inherently possessed by all human beings in virtue of their humanity. Such incongruity leads to a theoretical conundrum, according to Schroeder: one must either adopt a religious conception of human dignity whose relevance to a secular philosophy of human rights runs suspect or relinquish the idea of universal human rights in favour of a Kantian conception which is ostensibly restricted to the subset of humanity that is capable of rational agency. In response, Schaber laid down a two-tiered defence of the fundamental significance of human dignity to the human rights discourse. On the one hand, he examines and attempts to refute Schroeder's 'three knockdown arguments' by undermining both the validity of her reasoning as well as the truth value of the premises on which each of her three knockdown arguments are based. And on the other hand, he argues that none of the reasons Schroeder put forth, even if accepted as true, are sufficient to warrant her central thesis according to which the discourse on human rights must abandon making any recourse to the concept of human dignity.

Although, admittedly, the claims defended here draw heavily on Schaber's pointed response and to that extent can be regarded as a rejoinder to his critique of Schroeder, this paper submits original and standalone reasons why Schroeder's 
reasoning is flawed. The arguments to be advanced link brilliantly to a conceptual framework that not only survives Schroeder's objection but at the same time helps fill perceptible gaps in Schaber's reasoning. What is more, this paper asserts that the notion of human dignity is inseparably tied to the intuition about human beings as holders of some basic bundle of human rights. This is not to say that, for an effort at refuting Schroeder's objections to succeed it is necessary to confer a positive proposal towards a plausible concept of human dignity. It suffices to simply undermine Schroeder's arguments against the thesis that human dignity underpins human right-claims. However, this paper also makes a case against separating the conjoined twins, and to that extent it must make a positive proposal as to how the relation between human dignity and human rights ought to be conceived. That evidently requires more than pinpointing perceptible flaws in Schroeder's reasoning and towards a positive theory of the nature, value, and normative force of human dignity. To that end, Schaber propounds an adequacy condition for a plausible theory of human dignity, precisely that the proposed theory must "account for the paradigmatic forms of the violation of human dignity" (Schaber, 2013, p. 159). However, he too seemed to have it backwards for the reason that before identifying some forms of treatment as paradigmatic violations of human dignity one must first be in possession of a substantive conception of human dignity on account of which such judgements are made.

The following section unpacks Schroeder's three knockdown arguments and attempts to lay bare their fundamental flaws.

\section{Three flawed reasons for rejecting human dignity as a basis for human rights}

Schroeder puts forth three arguments in defence of her claim that we should abandon pursuing a dignitarian foundation of human rights, which she respectively labelled as "the justification paradox", "the Kantian cul-de-sac" and "hazard by association." There is no need to restate Peter Schaber's pointed remarks on each of her three arguments. I shall, however, put forth new insights into an approach at rescuing human dignity from radical sceptics such as Schroeder.

Human dignity admits plurality of meanings, and there cannot be one canonical interpretation of the term fit for all discursive contexts. Schroeder holds that all the morally relevant meanings to the term can be classified under two contrasting categories: inviolable dignity and aspirational dignity. Inviolable dignity comprises of specific conceptions that are based on the intuitive idea that human dignity is an inalienable normative property have by all human beings. Specific conceptions under this category principally include "traditional Catholic 
Kebadu Mekonnen Gebremariam

dignity" and Kantian dignity. Aspirational dignity, on the other hand, reflects distinctions in status owing to one's accidental place in birth, or individual characteristic traits such as moral and intellectual virtues and comportment. It consists in "aristocratic dignity," "comportment dignity," and "meritorious dignity". Aristocratic dignity is closely tied to the notion of (superior) social rank whether ascribed on the basis of purportedly inherent attributes acquired at birth or on the basis of merits accomplished by one's own effort. In this respect, rank reflects some salient features of the Roman dignitas. On the other hand, comportment and meritorious dignity function within the realms of virtue ethicsconstituted by, in the case of the first, "the outwardly displayed quality of a human being who acts in accordance with society's [rather contingent] expectations of well-mannered demeanour and bearing", and by observance to objective standards of virtue "which subsumes the four cardinal virtues and one's sense of self-worth", in the case of the latter (Schroeder, 2012, p. 332).

In her view, the controversy surrounding the concept of human dignity is reducible to the recognizable, albeit inherent, tension between these two categories of dignity. The dispute whether human rights are derived from human dignity will be pointless so long as this contradiction stays unresolved, argues Schroeder. That is to say, a plausible account of human dignity should be at hand before considering its precise normative function in the constitution of human rights. However, given this rather messy discourse on human dignity, Schroeder insists, human rights' theorizing should better abandon the purchase of human dignity and instead seek out alternative routes at grounding human rights. In addition, the attempt to ground human rights with a relatively more obscure notion of dignity constitutes "hazard by association". Foundational concepts ought to be clear, unambiguous and must elicit less controversy; however, dignity admits a number of mutually exclusive, perhaps equally valid, contextual interpretations. It makes more sense to ask, "which dignity?" than to ask, "which human rights?". It is, thus, unclear which contextual interpretation to consider as a foundation for human rights. That is by far Schroeder's most compelling argument (in the sense that it illustrates her point with some measure of philosophical lucidity) against dogmatic adoption of the familiar view that human rights are founded on the inherent dignity of the human person.

Compelling as that may be in locating uncritical deployment of the concept of human dignity, we must also be equally suspicious of the blanket rejection of any attempt at grounding human rights in human dignity. After all, being controversial is no argument for abandon and does not weigh heavily on a concept of such enormous significance. Evidently, 
There are various [incompatible] understandings of other normative and descriptive concepts as well [for example], of justice, fairness, autonomy, respect for persons and so on. In none of these contexts would disagreement about the meaning of the relevant concepts be accepted as a reason for giving up the concept; they would more likely be seen as a good reason for continuing the discussions about the right understanding of the term in question. (Schaber, 2013, p. 158).

Why should that be any different for the concept of human dignity?

In what follows, I shall put forth the reasons why I think Schroeder's claim should be rejected. In the first place, the described list of meanings to dignity does not portray a clear distinction, nor does it exhaust all morally relevant meanings that human dignity might convey.

In the first place, Schroeder's two distinctions in dignity are beset by an error of equating inherence with inviolability. A property or characteristics inherent to the human person doesn't necessarily command inviolable normative force. Inherence entails that a property is innate, built-in or is constitutive to its holder. Inviolability, on the other hand, implies a unique normative relation that moral agents ought to have in relation to the object of moral concern. A property is either inherent/intrinsic or extrinsic, but whether inherent properties are inviolable (resistant to trade-offs) is a matter of higher order normative consideration. That is why the notion of 'inviolable property' would be absurd. Take the capacity for laughter, for example, an inherent property of the human person; any right pertaining to the free exercise of this wonderful human capacity is not by definition immune from violation or infringement under any circumstances. To use a more extreme example, it seems fair to say that our capacity for cruelty is as inherent as our capacity for kindness, mercy and reverence for life. And yet, it would be contradictory to confer inviolability towards these opposing but equally inherent elements of the human nature. Incidentally, there is a convenient tradition in moral reasoning to infer inviolability directly from inherent properties rather than from properties contingently held by persons regardless of how morally salient those qualities might be at the time of attribution. Nonetheless, claims of inviolability are not given by inherence. And on the flip side, most legal rights enshrined in national constitutions are framed to be inviolable but arguably not all of them are attached to inherent attributes of the human person; a similar thing can be said about a number of rights under the International Covenant on Economic, Social and Cultural Rights. 
Kebadu Mekonnen Gebremariam

Now recall that Schroeder categorised 'aristocratic dignity' under the class of aspirational dignity. However, most of the prominent conceptions of 'aristocratic dignity' are best characterised as epitoms of inviolable dignity rather than of aspirational dignity. Aristocratic orders of rank, as a matter of historical fact, were established as if they were perfect embodiments of the natural order of things. The natural order was conceived to embody values that must be respected, not just descriptions of the way things are. Moreover, the dignity invested on the superior rank was defended as inviolable to the extent that the supposed hierarchical scheme of things reflects the fundamental normative moral order. Any society, pastime, present, or merely imaginary, that established caste systems of one type or another, characteristically defend its claim for differential moral status by resorting to a fitting (although mistaken) natural law theory. Consistent with the theoretical framework within which aristocracy operates, the dignity accorded to the highest social class is by definition inherent to their person. Consequently, the respect that the dignity of the aristocrat commands, by the same reasoning, was presumed to be inviolable. In contemporary societies, this obsolete aristocratic hierarchy manifests in relation to the differential moral concern we now accord to human beings in contrast to other animals.

It may not be accurate to say that aristocratic dignity accords unequal status to persons when it discriminates some class of people from others; instead, it narrows down the category of persons capable of full moral agency only to a subclass of people that nature has presumably graced with superior attributes and are entitled to full personhood by that account. Apologists of aristocratic moral systems attach the legitimacy of 'what is' (the status-quo) to the degree to which it reflects what ought to be. Thus, the origin of aristocratic moral status is both purportedly inherent to the human person (person defined in that narrow sense) and is also informed by a policy of equality of respect.

Given what has been stated in the above, one can now easily discern an essential congruence between 'aristocratic dignity' and the religious temperament upon which the traditional Catholic dignity is predicated. That is to say, aristocratic conception of dignity as rank is best classified under Schroeder's first category of dignity, which she termed as 'inviolable dignity'. Now that aristocratic dignity is reclassified under the first category, we now have a more consistent basis of distinction. It may be asked: what relevant difference does such change make with respect to the effort at refuting Schroeder's main thesis? Simply put, the introduction of this subtle change at the very least destabilises the presumably inherent tension between the two categories of dignity- namely inviolable and aspirational dignity. 
Secondly, the two categories of dignity are not mutually exclusive, that we can propound an overarching theory that conceives them as compatible without losing sight of the specific foundational issue in question. We do not need to abandon recourse to aspirational dignity in order to advance the view that human rights derive from the inherent dignity of the human person. It may still be argued reflection on the foundation of human rights is the domain of the normative framework within which inviolable dignity is to be found. Whereas, comportment dignity that is the sort of dignity invested in virtue or character is not compatible with a normative system that underpins the distinctive moral commands human rights allegedly envelop. Linking dignity with virtue, merit, or in accordance with comportment abilities would effectively exclude a significant number of human beings, and for that reason, argues Schroeder, "have no place in discussions about [the foundation of] human rights." That is a valid point, but it has little bearing on the judgement whether inviolable dignity grounds human rights.

Aspirational dignity may still be argued to play a vital, though not foundational, role in the constitution of rights. In exercising our rights, a capacity (and virtue) for moral self-restraint is a necessary ingredient that a person with dignity should possess. Dignity viewed as self-control balances compulsive, obsessive and unrestrained claiming of a bumptious person on the one hand, and at the same time encourages against a passive acceptance of violations of rights by a despondent person. She writes: "While having and exercising certain rights is important to our dignity as human beings, what we commonly regard as essential to human dignity would not be explained even if we were to delineate all of the relevant rights and the particular ways in which each of them expresses or protects human dignity." (Meyer, 1989, p. 521). For human rights to be of any significant moral function, setting aside, for now, what might justify them, they ought to be attached to "our ability to make these rights serve our own ends", which in turn requires a minimal capacity for self-control. Michael J. Meyer advances this view when he writes: "Though human rights do perform a moral function (the moral function of obliging others to respect us by way of respecting some of our most basic claims), what makes their function moral is the fact of the human capacity for authentic self-control" Meyer, 1989, p. 534). Each of the two components of the moral function that human rights perform are underpinned by two distinct but complementary notions of human dignity: the morality of respect by inviolable dignity and the latter-the ethical responsibility of the holder of rights to make a morally compelling use of her rights in a manner that reflects one's authentic self-control-by aspirational dignity. 
It may be the case that inviolable dignity and aspirational dignity are different limbs of the same ethical/moral nexus that constitute a unified system of values; I see nothing troubling in that, much less a fundamental tension between the two. Furthermore, following Ronald Dworkin one may declare that the inviolable/aspirational dichotomy perfectly illustrates the analytic distinction that he champions-namely, between the ethical and the moral realms. Aspirational dignity reflects one's ethical responsibilities for living well while inherent dignity supplies the moral dimension for the overall unified system of values (Dworkin, 2011). According to Dworkin, dignity is attached to two ethical principles: selfrespect, which requires taking seriously the objective importance of one's life; and authenticity which entails that the individual takes personal responsibility for cultivating a life that is consistent with one's own professed narrative of what counts as success in life. These two principles of dignity perform two complementary normative functions: on the one hand, they guide our ethical life by instructing us how to live well while in pursuit of a coherent and objectively valuable path in life, and on the other hand they "elucidate the rights individuals have against their political community" within the framework of interpersonal moral duties that they owe to one another. Consequently, Dworkin advances a conception of human dignity that unifies the realm of self-referent ethical responsibility with categorical moral duties of respect and equal concern for others. He writes,

Each person must take his own life seriously: he must accept that it is a matter of importance that his life be a successful performance rather than a wasted opportunity. I'm talking about dignity. It's a term overused by politicians, but any moral theory worth its salt needs to proceed from it (Dworkin, 2011, p. 203).

Even though the ethical and moral are analytically distinct realms yet normatively reinforce one another, the same thing can plausibly be said about aspirational and inviolable dignity. That is to say, a plausible theory of human dignity ought to integrate the two perspectives into an overarching and allencompassing value theory-in the words of Dworkin, a theory of justice for hedgehogs.

This is therefore to say that the perceived tension between the two categories of dignity is illusory as both meanings can plausibly be formulated in ways that beget no contradiction. It follows that Schroeder's argument-which states that 
deploying human dignity at the foundations of human rights would bring "hazard by association," does not hold.

\section{The justification paradox?}

Schroeder maintains that an attempt to ground human rights in human dignity will unavoidably lead to a 'justification paradox.' What she meant by the justification paradox reads as follows: should we adopt a secular conception of human dignity we ought at the same time have to abandon assigning human rights to all human beings in virtue of their humanity, whereas, according to Schroeder, "[i]f we want to use dignity as a foundation for human rights and accord all human beings human rights, then only the Traditional Catholic understanding of dignity is appropriate". Without reference to religious authority, she argues, human dignity loses its egalitarian ethos and, thus, any substantive deployment of dignity shall backpedal from the formidable progress we have made in terms of conferring equal respect and concern to all human beings. Appeal to religious authority is peculiar to the 'dignity axiom', whose normative relevance to secular morality runs suspect. If one, however, wants to get rid of the problematic religious or metaphysical pillar of the concept, one must at the same time be ready to abandon the idea that all human beings possess dignity in virtue of their humanity.

Schroeder's argument for a justification dilemma, however, rests on one fundamental but flawed premise, which asserts that an idea of human dignity have by all human beings must necessarily be coloured by the "religious sentiment". Conversely, the most philosophically compelling secular view, namely, the Kantian conception, does not appear egalitarian. However, that thesis rests on a false dichotomy. To be clear, hardly any of the distinguished scholars of Kant subscribe to Schroeder's arguably shallow reading of Kant on human dignity (see Sensen, 2011). Even if we assume, for the sake of argument, that Kantian dignity as inegalitarian, that do not mean we are left with just one other alternativenamely the traditional Catholic dignity or a similar conception with equivalent religious underpinnings.

The recent discourse on human dignity is invariably marked by a diversity of competing views with respect to the nature and value of human dignity. For instance, Jeremy Waldron propounds a rank/status conception of human dignity that is also purportedly foundational to human rights had by all human beings; Ronald Dworkin defends an ethical theory which encapsulates a concept of dignity that underpins moral duties we owe to each other including fundamental entitlements that we call human rights; Stephen Darwall suggests that it is more plausible to conceive of human dignity as the moral authority that serves as the 
underlying basis of interpersonal morality. These examples illustrate that human dignity did not sever its tie with the egalitarian ethos when religion lost its normative grip on moral thinking. Dignity's recent currency in moral and legal reasoning is merely indicative of the enormous potential that lies beneath the apparently messy surface. But to contend that the human rights discourse must quit taking seriously a dignitarian foundation of rights would amount to unduly restricting the limits of the possible with what's apparently given by the actual.

Moreover, Schroeder's understanding of a normative foundation excludes the possibility of foundational pluralism. I take issue with her generic and wholesale approach to the question: what, if anything, justifies human rights? In answering such question, the supposition that human rights are universal-that they are possessed by all human beings, has little bearing on the issue whether those rights are underpinned by a single overarching norm or by plurality of normative principles. The idea of a singular overarching foundation of human rights is not given by their egalitarian distribution. One promising approach is to reflect on whether the talk of dignity as a basis of human rights is compelling in light of foundational pluralism.

Some promising conceptions have it that, it is more plausible to think of human dignity as foundational to some rights and not to others (at least not directly). Whereas some of the fundamental human rights may be derived directly from human dignity, others are grounded on autonomy, or other moral values "without regard to the place those ideas have, in turn, in the analysis of dignity" (Waldron, 2013, p. 5). And consistent with our intuitive attachment of the concept with paradigmatic violations of human rights, dignity may be germane to some rights than others. Oftentimes, the notion of respect for human dignity manifests through our indignation towards torture or slavery or other incidents of humiliating and dehumanizing treatment of persons more emphatically than, for instance, the reactive attitudes we find fitting to violations of the right to work or a right to periodic holidays with pay. Some of the human rights-claims declared under in the Universal Declaration of Human Rights, specifically those listed under economic, social and cultural rights, are not clearly inspired by human dignity and perhaps not derived from it.

Moreover, the notion that human rights are universal does not necessarily presuppose that all human beings actually possess the exact same catalogue of rights regardless of their specific circumstances of being. On the contrary, biological determinants of either the developmental or the accidental sort (for instance, children or the mentally disabled) or factors that are merely contingent (example, a Robinson Crusoe living in virtual isolation), may determine the actual 
roster of human rights that individuals may happen to possess or lack thereof "due simply to the fact that it would make no sense to ascribe rights to beings who are in principle unable to exercise them" (Schaber, 2013, p. 158).

However, no one loses one's dignity just because he or she is in principle incapable of being possessed of certain rights. Could that be evidence against the universality of human rights or a reason for discounting human dignity as their possible basis? Evidently, some rights pertaining to moral self-legislation including the right to autonomy can be withheld or severely restricted from a specified category of human beings such as children and adults suffering from advanced stages of dementia. If the mentally disabled are accorded moral protection consistent with their equality in rights and dignity-a full state of equality which one can say children are born to though they are not born with it, that indicates the implausibility of adopting a strict interpretation of the Kantian theory according to which human dignity is predicated solely on moral selflegislation. This is simply to say that, the (normative) fact of some people lacking certain rights does not falsify the general proposition that "all human beings possess certain rights in virtue of their humanity."

Not all theories of rights, and certainly not all Kantians, postulate the rightholder's capacity for moral self-legislation as a singular grounding factor for assigning rights to her, although for Kantians moral agency rests on the rational capacity for self-legislation. I shall not revisit the debate whether moral selflegislation is the sole adequacy condition for determining whether a norm or imperative is morally binding. It suffices to say the following. One can still be a subject, i.e. a holder, of human rights even though incidentally one's capacity for moral agency has been totally undermined, as it was, by a debilitating mental illness or psychosis. He may no longer be considered as a moral agent (in the sense that his intentions and actions are subject to moral evaluation) up until an adequate measure of his moral-psychological functioning is restored. Be that as it may, it would be too much of a stretch even for a Kantian to believe that moral selflegislation is what confers a compelling moral force for basic moral rights such as the right to life.

The supposition that some human beings may not have certain rights, whether problematic or not in and of itself, engenders a peculiar problem to the foundation of human rights. As rightly noted by Schaber: "The question is whether the fact that human beings do not have certain rights in virtue of being members of the human species is a special problem for a dignity foundation of human rights, as opposed to any foundation of human rights" (Schaber, 2013). 
Similarly, the question "why should being human be a reason for having certain rights?" is indispensable for understanding the fundamental fabric of "rights morality'. Reference to our common humanity ought not be understood in the strictly biological sense; of course, although in many ways it implies that we are of the same natural kind.

The common humanity relevant to the possession of human rights must be understood as a normative concept that no single or a cluster of descriptive properties of the biological person can adequately capture, without meaning to say that our intellectual and psychological make up, moral sensibilities, an underlying social psychology, capacity to pleasure, and our vulnerabilities to pain and suffering are irrelevant to it. Our common humanity and the most fundamental claims that protect it ought not be divorced from the human condition, but that don't mean a mere description of what constitutes the human condition could by itself generate a categorical moral force that human rights are imbued with.

\section{Toward a criterion for a plausible conception of human dignity (that does not generate a justification paradox)}

In total accord with Schaber, it is imperative to table some criteria on what may count as an adequate conception of dignity that can justify human rights. It is immediately evident that some conceptions of dignity are not suited to be directly foundational to human rights. Those conceptions belonging to, in Schroeder's taxonomy, the class of 'aspirational dignity' might not satisfy a modest justificatory criterion. Nevertheless, specific conceptions of aspirational dignity do still have important role to play in terms of underscoring the value that deriving a proper moral function from rights has for a worthwhile life. Furthermore, virtueethical conceptions of dignity inform us the categorical nature of our ethically responsibility we carry ourselves with dignified bearing, such that meaningful life is to be found in the voluntary act of carrying out the burdens and opportunities of life and in doing that with dignified bearing.

The line separating the ethical and moral conceptions of human dignity also cuts across two distinctions of value introduced in the literature by Elisabeth Anderson, namely between appealing value and commanding value (Anderson 2008). What we learn from Kant's deep insight into the structure of values, Anderson argues, is that we grasp dimensions of value through our feelings. Values come either as appeal or as command, and we respond to each in dramatically different ways. "Appealing values constitute the domain of the good, commanding values the domain of the right" (Anderson 2008, p. 123). The idea of human dignity as a commanding value may originate in the ethics of honour which 
assumed, as it was, that persons with unmatched moral integrity are to be accorded the highest respect and moral difference. But, before the emergence of Kant's moral theory a strict distinction was not drawn between the respect commanding and the comportment expressing component of dignity as honour. We can now draw a distinction between dignity as comportment or honourable demeanour and dignity as a claim by which all rational beings exact or demand respect from one another (MM, 6, p. 435). Failure to respect dignity as a commanding value implies violation of a categorical moral injunction, that is to mean dignity violations are to be considered not only as morally wrong but also constituting personal offense (Feinberg, 1987 \& 1988).

Respect for human rights also takes this deontic form on a par with a fitting attitude that Kant attaches to respect for the dignity of persons. Consequently, the underlying normative framework (within which human rights as well as human dignity are to be found) ought to confer victims of violations a moral mandate to demand, in the sense that individuals are morally sanctioned to address each other with- "you owe me!" (Feinberg, 1970 \& Darwall, 2006). In other words, the moral sanction predicated on being possessed of human dignity ought to constrain us in such a way that we are answerable to one another. The upshot is that, such adequacy condition shall render a deontic account of human dignity on a consistent footing with the logic of rights, which will, in turn, locate the adequate justificatory locus of the concept.

To be clear, other normative frameworks may require us be morally accountable to one another, although not in the strictly personal sense. Take 'dutybased morality' for example. On this approach to morality, a person towards whom a duty is breached is not in a unique position to demand that it be rectified: a third party may be equally authorized to do so. Perhaps moral criticism is the most appropriate response to non-observance of duty. If I am disinclined to perform my duties regarding the fellow next door, if anything, I won't owe it to him any more than I would to an innocent bystander who is not affected whatsoever by my attitudes and actions. Respect for dignity can be viewed in this light. But viewed as such, dignity will ultimately fail to fit into the theoretical system within which the concept of rights operates. A proponent of 'duty-based morality' may consistently respond to claims for respect for dignity that are directed at him with a conviction that rational persons are self-legislating and, hence, are solely answerable to the moral law which they would voluntarily subject themselves to. Such reply has an uncanny resemblance to, and thus be considered as a secular version of, the famous biblical interjection which reads: "To Thee only have I sinned" where in our case reference to God is replaced by the moral law. 
This is thus to say that an adequate understanding of dignity must reflect what Anderson calls a commanding value, which combines the requirement for respect with the value's ostensibly categorical moral grip. Secondly, it must also designate a moral authority by which one can demand respect from all other human beings. It is precisely this fundamental normative standing of persons (a principle that protects essential components of human subjectivity) that some philosophers characterise as human dignity. It encompasses "the respect we must show people just out of recognition of their status as people" (Dworkin, 2011, p. 205). Similarly Schaber contends that, "an adequate understanding of dignity has not just to account for the core human rights; it has also ... be able to explain why, for instance, the humiliation of people is a violation of dignity, or why discrimination against people violates dignity" (Schaber 2013, p. 159).

The idea that as a fundamental normative standing of persons human dignity protects human subjectivity elicits little controversy. It goes without saying that some human rights-claims are more germane to the protection of human subjectivity than others, and for that reason can be directly underpinned by the principle of human dignity. It remains an open question whether dignity underpins only some of the core human rights while other normative concepts accounting for the reminder of human rights-claims. The core human rights- namely the human right to liberty and security of the person, the right not to be enslaved, prohibitions against torture and inhuman treatment, safeguards against humiliating and degrading treatment- clearly protect the moral status of human beings. The claim that most fundamental human rights protect the moral status of individuals does not in itself warrant that all human rights are derived from human dignity. In order to prove the latter, I must admit that more argument is required than simply demonstrating that human dignity is normatively prior to human rights.

Nevertheless, an adequate conception of human dignity should be found within a normative framework which permits a unique spectrum of what Strawson (1962) termed as (participant) reactive attitudes. Indignation and humiliation are reactive attitudes specifically attached to the notion of respect for human dignity. Of course, the moral grip that reactive attitudes like a feeling of humiliation might have for underscoring inter-personal moral relations needs to be clarified in precise and unambiguous terms. In moving towards that end, an adequate theory of human dignity must explain and account for why certain instances of (subjective feelings of) humiliation and indignation are (or would be considered) morally warranted and why some ar not (Strawson, 1962, p. 2). On the one hand, not every instance in which someone claims to have been subjected to humiliation is ipso facto justified, and on the other hand, not every 
violation of human rights is at the same time occasioned by a justified feeling of humiliation. Corollary to that, humiliation is often constituted by the manner in which some rights are violated, rather than by the simple fact of a right's violation. One may have a justified feeling that one's self-respect is injured when one is treated as if he/she counts for nothing, even though such act was occasioned by a very minor infringement of a right. This requirement should be viewed independently of the question whether human rights are grounded on human dignity.

However, the revelation that respect for human dignity is more germane to moral prohibitions against humiliating and degrading treatment of persons has two significant ramifications for the question of justification. Firstly, it attests to the idea that human dignity is not extensionally identical with human rights, which, in turn, debunks the most trenchant criticism that human dignity is redundant. And secondly, if a stringent moral condemnation is warranted due to the humiliating gestures with which minor infringements of a right are committed, that reinforces the claim that respect for human dignity is normatively prior to respect for rights. The cumulative force of these two ramifications confers a prima facie reason for thinking that human rights are founded on the inviolable dignity of the human person.

To reiterate, an adequate conception of human dignity should fulfil two conditions in order to be considered as a foundation for human rights: First, it must vindicate the most basic human rights in so far as basic rights are understood to be those rights that directly protect the core constituents of human subjectivity; secondly, such a theory has to be predicated on a normative framework within which reactive attitudes such as the feeling of humiliation and indignation could be uniquely tied to the idea of respect for human dignity.

\section{Human dignity as the moral standing for having rights}

Positive insights from our considered reflections about paradigmatic violations of human dignity and the structure of reactive attitudes that they warrant, confer a prima facie support to the view that human dignity is a specific moral status/standing of beings that are possessed of having rights. Such view can be cashed in terms of two contrasting conceptions of human dignity.

It may be interpreted along the lines of Jeremy Waldron who contends that dignity is a normative status that not only underpins human rights but also serves as a content of some rights. This reading stipulates a dualistic understanding of the 
relationship between human dignity and human rights. On the one hand, "dignity is a normative status and that many human rights may be understood as incidents of that status" (Waldron 2012, p. 18). And on the other hand, some rights may be understood as more germane to the protection of this underlying normative status of persons. We are said to have the human right against "outrages on personal dignity" including specific protections against torture, cruel, inhuman, degrading and humiliating treatment of persons. These rights have a direct bearing on our standing as beings with human dignity, whereas some welfare rights, for instance, may be conceived as a little far off that mark.

Peter Schaber, on the other hand, defends the view that human dignity is the normative authority and itself a general moral right which grants individuals "the authority to do what one wants with regard to whatever falls within the purview of one's authority" (Schaber 2013, p. 160). This normative authority, that Schaber equates with human dignity, comprises "anything that is important in my life- for example, who I live with, who I marry, what profession I choose, what projects I take up, etc" (Schaber, 2013). This particular reading of the specific normative status we all have in virtue of our humanity, strikes accord with the juridical interpretation of human rights. Schaber's interpretation appears to endorse the familiar legal tradition of declaring human dignity as inviolable and went on cashing it in terms of a specific right that prohibits "outrage against dignity".

The difficult thing here is not to identify what falls within the boundaries of our normative authority but to identify what falls outside its purview, unless one wishes to include the entire archive of codified human rights law within the ambit of normative authority. Schaber opts for the latter path when he writes, "it is not just liberty rights which protect the normative authority of human beings, but also social and cultural human rights such as the right to an adequate standard of living (Art. 25), the right to a basic education (Art. 26 ), and the right to freely participate in the cultural life of the community (Art. 27)." Apparently, anything (objectively) important in one's life can be fitted within the realm of normative authority, in which case any right violation would automatically constitute a violation of human dignity. This is both counterintuitive and may also lend itselfto inflationary deployment of the concept of dignity.

Moreover, the supposition that normative authority is an overarching right engenders a 'justification paradox' (though not of the kind that Schroeder argued any secular conception of human dignity would). Here is the conundrum: in declaring normative authority as just another (albeit an overarching) moral right, we may fall back to the very same foundational question we 
began our analysis with. If as normative authority dignity is a fundamental moral right, then it requires an underpinning of the sort we find compelling which would in turn underpin specific human rights-that reflect dignity. That would be a double bind, hence, back to square one.

Contrariwise, Waldron's interpretation of dignity as moral status appears more promising. It can accommodate, also confer an adequate explanation for, the proposition that a moral offense can both be a paradigmatic violation of human dignity and at the same time a human right violation. Take torture for example. Cruel intentions and severe physical and psychological scars to be sustained weigh heavily on the reason why torture constitutes a violation of basic human right. Humiliating and degrading victims is intrinsic to the logic of torture, so is sadistically subjecting them to intolerable pain and suffering for the purpose of breaking their will and thereby reducing them to obedient automatons. But that is not all there is to say about the moral offense that torture manifests. What is also morally repugnant about torture is the underlying attitude of treating the victim merely instrumentally, as if the person counts for nothing. An argument can be produced why torture constitutes a violation of human dignity, whereas violation of a right to periodic holidays with pay might not. A stark distinction in moral stringency between these two offenses is made possible by adopting the view that dignity is the moral status of persons as being possessed of rights.

\section{Conclusion}

If the claims defended here are correct, which I believe they are, they can effectively disarm the general objection that human dignity is at best a redundant and at worst a useless concept. This paper systematically showed fundamental flaws in Schroeder's three knockdown arguments against taking seriously the familiar claim that human rights derive from the inherent dignity of the human person. That only takes us half way, for a complete defense of human dignity one must also propound a positive account of its nature, value, and moral grip. The second half of this paper was designed to serve that end, in which significant space was devoted to the articulation and defense of human dignity as a moral standing of persons regarded as beings of the kind that are possessed of human rights. Taking morally appalling episodes in human history seriously, we may be able to discern that the moral stringency of a rights violation is inextricably tied to the context in which such violation occurs. 
For instance, disenfranchising minorities may warrant stringent moral sanction than a decontextualized imagination of it might suggest. Obviously, violations of the right to vote ought not to be understood as having a similar degree of moral offensiveness as slavery and torture, since the latter have the potency to strip people off their humanity. But a right to vote may be denied in ways that invoke the dignity claim in the same way as torture and slavery would. Often times, totalitarian regimes have summarily denied voting rights to all their citizens, but that does not necessarily reflect a manifest denial of the humanity of the people under their rule. However, denial of voting rights to some targeted groups such as religious and racial minorities produces a rather different moral problem, since in most cases such denial of rights is grounded on the conviction that the denied are of lesser humanity than the privileged. Jim Crow laws are of the kind that deny the equal moral standing of coloured people, whereas, in contrast, unduly stripping civil rights off ex-convicts on the basis of their (past) actions and character deserves a comparatively weaker moral condemnation. What drives the wedge in moral stringency between these two contextual violations of the same right is whether or not such violation of a right is also occasioned by the intent to humiliate, degrade, or otherwise to dehumanize persons on the basis of distinctive features that are irrelevant from the moral point of view. The line that colours such division is precisely the notion of respect for human dignity.

There is another way of looking at the problem of normative foundation for human rights. Setting aside the adequacy conditions for determining the extent to which a specific right's close tie to human dignity enhances its contextual moral stringency, it is generally true that human rights "have their home in normative systems with constructed personae." (Wenar 2013, p. 229). Determining the nature of the 'moral personae' that human rights are meant to protect is crucial for identifying what human rights there are, whereas failing to make such determination would mean that we might as well remain ambivalent about what human rights there are. The role of human dignity as a possible ground for human rights relates to meeting the conditions under which human rights ascriptions are valid, which includes defining the underlying 'human moral personae'. Human dignity reflects that we are beings of the sort whose moral standing has it that we ought to be endowed with inviolable rights. An inquiry into the underlying normative structure within which human dignity is to be found is a task of immense significance which a modest paper like this cannot do justice. 


\section{Acknowledgement}

I am grateful to Holger Baumann, Peter Schaber, Hubert Schnüriger, Human Dignity Working Group at the Center for Ethics of the University of Zurich, and the two anonymous reviewers for helpful comments. 


\section{References}

Darwall, S. (2006). The second-person standpoint: Morality, respect, and accountability. Cambridge, M.A.: Harvard University Press.

Dworkin, R. (2011). Justice for hedgehogs. Cambridge, MA: Harvard University Press.

Ernst, G., \& Heilinger, J-C (eds.). (2012). The Philosophy of human rights: Contemporary Perspectives. Berlin: De Gruyter.

Feinberg, J. (1987). The moral limits of the criminal law volume 1: Harm to others. Oxford: Oxford University Press.

Feinberg, J. (1988). The moral limits of the criminal law: Volume 2: Offense to others. Oxford: Oxford University Press.

Feinberg, J. (1970). The nature and value of rights. Journal of Value Inquiry, 4(4), 243-260.

Gebremariam, K. M. (2016). Human dignity and moral rights (Monograph). Zurich: University of Zurich. Retrieved from: https://doi.org/10.5167/uzh136562.

Gewirth, A. (1992). human dignity as the basis of rights. In Meyer, M. J. \& Parent, W. A. (Eds.), The Constitution of Rights: Human Dignity and American Values (pp.10-28). Cornell University Press.

Griffin, J. (2008). On Human rights. Oxford: Oxford University Press.

Habermas, J. (2010). The concept of human dignity and the realistic utopia of human rights. Metaphilosophy, 41(4), 464-480.

Keteb, G. (2011). Human dignity. Cambridge, M.A.: Harvard University Press.

Margalit, A. (1996). The Decent Society. Cambridge, MA.: Harvard University Press.

McCrudden, C. (Ed.). (2014). Understanding human dignity. Oxford: Oxford University Press.

McCrudden, C. (2008). Human dignity and judicial interpretation of human rights. The European Journal of International Law, 19(4), 655-724.

Meyer, M., J. (1989). Dignity, rights and self-control. Ethics, 99(3), 520-534.

Rosen, M. (2012). Dignity: Its history and meaning. Cambridge, M.A.: Harvard University press.

Schaber, P. (2013). human rights and human dignity: a reply to Doris Schroeder. ethical theory. Moral Practice, 17(1), 155-161.

Schroeder, D. (2012). Human rights and human dignity: an appeal to separate the conjoined twins. Ethical Theory Moral Practice, 15, 323-335.

Strawson, P. F. (1962). freedom and resentment. Proceedings of the British Academy, 48, 1- 25. 
Tasioulas, J. (2012). Towards a philosophy of human rights (Inaugural lecture as Quain professor of Jurisprudence). University College London.

Tasioulas, J. (2013). human dignity and the foundations of human rights. In, Christopher McCrudden (ed.), Understanding Human Dignity (pp.293-314). Oxford University Press.

Valentini, L. (2017). Dignity and human rights: A Reconceptualisation. Oxford Journal of Legal Studies, 37 (4), 862-885.

Velleman, D. (1999). A right of self-termination? Ethics, 109(3), 606-628.

Waldron, J. (2009). Dignity, rank and rights: the Tanner lectures at UC Berkeley (Public Law Research Paper No 09-50). NYU: School of Law

Retrieved from: http://ssrn.com/abstract=1461220

Waldron, J. (2012). Dignity, rank and rights. Oxford University Press.

Waldron, J. (2013). Is dignity the foundation of human rights? Public Law and Legal Theory Research Paper Series (Working Paper No. 12-73), 1-29.

Wenar, L. (2013). The nature of claim-rights. Ethics, Symposium on Rights and the Direction of Duties, 123(2), 202-229. 